\title{
Gallium Ga 68 OPS202
}

National Cancer Institute

\section{Source}

National Cancer Institute. Gallium Ga 68 OPS202. NCI Thesaurus. Code C116710.

A radioconjug ate consisting of the somatostatin antagonistic peptide OPS202 that is labeled with the positron-emitting radionuclide gallium Ga 68 , which may be used as a somatostatin receptor (SSTR) imaging agent in conjunction with positron emission tomography (PET) to image neuroendocrine tumors (NETs). Gallium Ga 68 OPS202 binds to SST R subtype 2 present on the cell membranes of many types of NETs. This allows for visualization of SST R-positive cells upon imaging. SSTR subtypes have been shown to be present in large numbers on NETs and their metastases, while most other normal tissues express low levels of SST R subtypes. 